\title{
Deteksi Kandungan Formalin dan Boraks pada Bakso Daging yang Dijual Di Kota Kefamenanu
}

\author{
Marianus Nahak Seran ${ }^{\mathrm{a}}$, Stefanus $\mathrm{Sio}^{\mathrm{b}}$ dan Kristoforus W. Kia ${ }^{\mathrm{c}}$ \\ ${ }^{a}$ Fakultas Pertanian, Universitas Timor, Kefamenanu, TTU - NTT, 85613, Indonesia, email: marianusnahakseran@gmail.com \\ ${ }^{b}$ Fakultas Pertanian, Universitas Timor, Kefamenanu, TTU - NTT, 85613, Indonesia, email: stefsio67@ gmail.com \\ ${ }^{c}$ Fakultas Pertanian, Universitas Timor, Kefamenanu, TTU - NTT, 85613, Indonesia, email: willyamkia10@ gmail.com \\ Article Info

\section{Abstrak}

\section{Article history:}

Received 26 Juli 2021

Received in revised form 01 Agustus 202 Accepted 10 Agustus 2021

DOI

https://doi.org/10.32938/ja.v6i3.1424

Keywords:

Bakso

Formalin dan

Boraks.
Penelitian ini bertujuan untuk mendeteksi keberadaan formalin dan boraks pada bakso daging yang dijual di Kota Kefamenanu. Penelitian ini dilakukan dengan mengambil 20 sampel bakso pada warung yang menjual bakso. Pengujian formalin dan boraks pada bakso dilakukan secara kualitatif yakni dengan melihat perubahan warna yang terjadi pada residu dari penambahan kurkumin $0,125 \%$ pada supernatan. Jika residu berwarna merah cerry maka boraks dinyatakan positif. Untuk pengujian formalin pada bakso secara kualitatif dilakukan dengan melihat perubahan warna dengan penambahan asam kromatofat, asam fosfat dan hidrogen peroksida pada filtrat. Jika terjadi perubahan warna menjadi merah keunguan menunjukkan bahwa sampel positif mengandung formalin.Data pengujian yang diperoleh dianalisis menggunakan uji statistik deskriptif berupa nilai persentasi. Hasil penelitian menunjukkan bahwa dari 20 sampel bakso yang diuji tidak terdapat formalin dan juga boraks. disimpulkan bahwa Produsen atau penjual bakso di Kota Kefamenanu, Kabupaten Timor Tengah Utara tidak menggunakan boraks sebagai bahan pengeyal bak so dan Formalin sebagai bahan pengawet pada pembuatan bakso.

\section{PENDAHULUAN}

Seiring dengan berkembangnya pengetahuan akan gizi, manusia semakin menyadari pentingnya mengkonsumsi protein hewani karena sangat dibutuhkan untuk proses pertumbuhan, perkembangan dan pemeliharaan kesehatan. Nilai protein daging yang tinggi disebabkan oleh kandungan asam amino esensialnya yang lengkap dan seimbang. Asam amino esensial merupakan pembangun protein tubuh yang harus berasal dari makanan karena tidak dapat dibentuk di dalam tubuh.

Saat ini telah banyak dijual produk-produk pangan olahan asal hewani. Salah satu hasil olahan tersebut adalah bakso. Bagi masyarakat Indonesia umumnya, bakso merupakan makanan yang tidak asing lagi karena hampi disetiap jalanan, sekolah, pertokoan bahkan perkantoran makanan ini selalu ada. Menurut Kamus Besar Bahasa Indonesia, bakso adalah makanan yang terbuat dari daging, ikan atau udang yang dicincang atau digiling dan dilumatkan bersama tepung kanji, biasanya dibentuk bulat-bulat.

Dalam pengolahan bakso umumnya menggunakan dua komponen yaitu bahan utama dan bahan tambahan. Bahan tambahan ini umumnya disebut sebagai bahan tambahan pangan (BTP) atau bahan tambahan makanan (BTM) atau food additive. Tujuan pemberian BTP adalah untuk mendapatkan pengaruh tertentu seperti (1) mengawetkan pangan dengan mencegah pertumbuhan mikroba perusak pangan; (2) mencegah terjadinya reaksi kimia yang dapat menurunkan mutu pangan; (3) membentuk pangan menjadi lebih baik, renyah dan lebih enak bila dimakan; (4) memberi warna dan aroma yang lebih baik dan lebih menarik sehingga menambah selera;(5) meningkatkan kualitas pangan dan memperpanjang masa simpan

Produk pangan asal hewani dewasa ini semakin beragam bentuknya, baik itu dari segi jenisnya maupun dari segi rasa dan cara pengolahannya. Namun seiring dengan semakin pesatnya teknik pengolahan pangan, penambahan bahan-bahan aditif pada produk pangan sulit untuk dihindari. Akibatnya keamanan pangan telah menjadi dasar pemilihan suatu produk pangan yang akan dikonsumsi.

Keamanan pangan merupakan hal yang sedang banyak dibicarakan, karena masyarakat semakin sadar akan pentingnya sumber makanan dan kandungan yang ada di dalam makanannya. Hal ini terjadi karena adanya produk pangan yang dapat membahayakan kesehatan masyarakat, sehingga diperlukan suatu cara untuk mengawasi keamanan pangan. Dalam proses keamanan pangan, dikenal pula usaha untuk menjaga daya tahan suatu bahan sehingga banyaklah muncul bahan-bahan pengawet yang amanbagi kesehatan dengan tujuan untuk memperpanjang masa simpan suatu bahan pangan. Namun dalam prakteknya di masyarakat, masih banyak yang belum memahami perbedaan penggunaan bahan pengawet untuk bahan-bahan pangan dan yang non pangancontohnya Formalin dan Boraks merupakan bahan pengawet non pangan tetapi kerapkali digunakan sebagai BTP. Oleh karena itu dalam penggunaannya sebagai BTP dalam suatu produk pangan dianggap tidak memenuhi syarat (TMS) karena dapat membahayakan kesehatan masyarakat.

Formalin merupakan antiseptik untuk membunuh bakteri kapang dan sering digunakan untuk mencuci peralatan kedokteran atau mengawetkan mayat. Formalin tidak boleh digunakan sebagai bahan pengawet untuk pangan Formalin biasanya digunakan sebagai pembunuh kuman sehingga banyak digunakan pada produk pembersih lantai, kapal, gudang dan pakaian Sedangkan boraks $\left\{\right.$ Natrium tetrabonat $\left(\mathrm{NaB}_{4} \mathrm{O}_{7} 10 \mathrm{H}_{2} \mathrm{O}\right)$ \} mempunyai sifat antiseptik yang jika dikonsumsi dalam jangka waktu yang lama dapa terakumulasi dalam tubuh sehingga menyebabkan keracunan. Boraks juga digunakan sebagai bahan solder, pembuatan gelas, bahan pembersih/pelican porselin, pengawet kayu dan antiseptik kayu. Tujuan dari penelitian ini adalah untuk mendeteksi keberadaan Formalin dan Boraks yang diduga ada dalam bakso daging yang dijual di Kota Kefamenanu.

\section{MATERI DAN METODE PENELITIAN}

Penelitian ini telah dilakukan pada bulan Juli sampai Agustus 2020 bertempat di Unit Pelakasaan Teknis Laboratorium MIPA Universitas Khatolik Widya Mandira Kupang.

\subsection{Materi Penelitian}

\subsubsection{Alat}

Alat yang akan digunakan dalam penelitian ini adalah: batang pengaduk, cawan porselin, spektrofotometri UV-Vis, sentrifuge, timbangan elektrik, labu takar, tabung reaksi, rak tabung reaksi, dan waterbath.

\subsubsection{Bahan}

Bahan dan pereaksi yang digunakan untuk mengidentifikasi boraks adalah: bakso yang diambil di Kota Kefamenanu, akuades, kurkumin 0,125\%, asam asetat, asam sulfat, etanol absolut, $\mathrm{NaOH} 10 \%$. Pereaksi yang digunakan untuk mengidentifikasi formalin adalah Asam asetat, etanol, $\mathrm{H}_{2} \mathrm{SO}_{4}$, pereaksi Nash, asam kromatofat, asam fosfat dan hydrogen peroksida.

\subsection{Metode Penelitian}

Penelitian ini dilakukan dengan cara pengambilan sampel secara purposive pada warung-warung yang menjual bakso di Kota Kefamenanu. Pengujian keberadaan formalin dan boraks pada bakso dilakukan secara eksperimen meliputi pengujian kualitatif dan kuantitatif.

\subsection{Prosedur Penelitian}

Persiapan sampel

a) Sampel dipotong kecil-kecil dan ditimbang sebanyak 25 gram, dimasukkan ke dalam labu takar $100 \mathrm{~mL}$ dan ditambah akuades sampa tanda batas.

b) Sampel diblender sampai halus, kemudian disentrifuse selama 3 menit dengan kecepatan $3000 \mathrm{rpm}$.

c) Supernatannya diambil untuk diidentifikasi dengan menggunakan metode analisis kualitatif dan kuantitatif.

\subsubsection{Uji kualitatif boraks}

a) Supernatan yang telah didapat diambil sebanyak $1 \mathrm{~mL}$ dan dimasukkan ke dalam cawan porselen.

b) Satu mL larutan asam sulfat pekat ditambahkan pada sampel.

c) Cawan porselen yang telah berisi supernatant dipanaskan diatas penangas air sampai kering, kemudian dilanjutkan pemanasan dengan oven pada suhu $100^{\circ} \pm 5^{\circ} \mathrm{C}$ selama 5 menit lalu didinginkan.

d) Tiga $\mathrm{mL}$ larutan kurkumin $0,125 \%$ ditambahkan pada supernatan kemudian dipanaskan sambil diaduk selama \pm 3 menit dan diamat perubahan warna residu yang terjadi, jika berwarna merah cherry maka boraks positif.

\subsubsection{Uji kuantitatif boraks (Spektrofotometer)} Penentuan panjang gelombang maksimun

a) Larutan induk boraks dibuat dengan menimbang $50 \mathrm{mg}$ serbuk boraks dalam $100 \mathrm{~mL}$ akuades sehingga konsentrasi menjadi $500 \mu \mathrm{g} / \mathrm{mL}$. Larutan induk boraks $500 \mu \mathrm{g} / \mathrm{mL}$ diencerkan menjadi konsentrasi 5 $\mu \mathrm{g} / \mathrm{mL} ; 10 \mu \mathrm{g} / \mathrm{mL} ; 15 \mu \mathrm{g} / \mathrm{mL} ; 20 \mu \mathrm{g} / \mathrm{mL}$, dan $30 \mu \mathrm{g} / \mathrm{mL}$ dengan mengambil sebanyak $0,5 \mathrm{~mL}$ untuk $5 \mu \mathrm{g} / \mathrm{mL} ; 1 \mathrm{~mL}$ untuk $10 \mu \mathrm{g} / \mathrm{mL} ; 1,5$ mL untuk $15 \mu \mathrm{g} / \mathrm{mL} ; 2 \mathrm{~mL}$ untuk $20 \mu \mathrm{g} / \mathrm{mL} ; 3 \mathrm{~mL}$ untuk $30 \mu \mathrm{g} / \mathrm{mL}$ dan 
dimasukkan ke dalam labu takar $50 \mathrm{~mL}$, kemudian ditambah akuades sampai tanda batas.

b) $1 \mathrm{~mL}$ larutan boraks dari masing-masing konsentrasi dimasukkan ke dalam cawan porselin, ditambah $1 \mathrm{~mL}$ larutan $\mathrm{NaOH} 10 \%$ lalu dipanaskan diatas penangas air sampai larutan kering, lanjutkan pemanasan dengan menggunakan oven pada suhu $100^{\circ} \pm 5^{\circ} \mathrm{C}$ selama \pm 5 menit lalu didinginkan.

c) Ditambahkan $3 \mathrm{~mL}$ larutan kurkumin $0,125 \%$, dipanaskan sambil diaduk selama \pm 3 menit dan didinginkan. Larutan ditambah $3 \mathrm{~mL}$ larutan asam sulfat dan asam asetat (1:1) sambil diaduk sampai tidak ada warna kuning pada cawan dan pengaduk, lalu diamkan selama \pm 8 menit. Larutan ditambah sedikit etanol kemudian disaring dengan kertas saring lalu dimasukkan ke dalam labu takar $50 \mathrm{~mL}$ dan diencerkan dengan etanol sampai garis tanda. Hasil saringan dikumpulkan dan diamati serapannya pada panjang gelombang maksimum yang telah diperoleh.

d) Larutan standar boraks $5 \mu \mathrm{g} / \mathrm{mL}$ dari boraks murni digunakan untuk menentukan panjang gelombang. Larutan yang sudah dipreparasi diamati serapannya pada panjang gelombang antara 400-600 $\mathrm{nm}$ menggunakan alat spektrofotometer UV-Vis.

\subsubsection{Penetapan kadar boraks dalam bakso}

a) Sampel yang telah dipreparasi dari bakso yang ditimbang 25 gram ditambah akuades $100 \mathrm{~mL}$ dan diblender kemudian disentrifuse, supernatannya dipipet sebanyak $1 \mathrm{~mL}$ dimasukkan ke dalam cawan porselin dan ditambahkan $1 \mathrm{~mL}$ larutan $\mathrm{NaOH} 10 \%$. Dipanaskan diatas penangas air sampai larutan kering, pemanasan dilanjutkan dengan menggunakan oven pada suhu $100^{\circ} \pm 5^{\circ} \mathrm{C}$ selama 5 menit dan didinginkan.

b) Larutan ditambah $3 \mathrm{~mL}$ larutan kurkumin $0,125 \%$, kemudian dipanaskan sambil diaduk selama \pm 3 menit dan didinginkan. Larutan ditambah $3 \mathrm{~mL}$ asam sulfat dan asam asetat (1:1) sambil diaduk sampai tidak ada warna kuning baik pada cawan maupun pada batang pengaduk dan diamkan selama \pm 8 menit.

c) Larutan ditambah sedikit etanol kemudian disaring dengan kertas saring lalu dimasukkan ke dalam labu takar ukuran $50 \mathrm{~mL}$ dan diencerkan dengan etanol sampai garis tanda. Hasil saringan diamati serupannya pada panjang gelombang maksimum yang telah diperoleh (Kresnadipayana dan Lestari, 2017).

\subsubsection{Uji Kualitatif Formalin (Asam Kromatofat)}

a) Sampel dipotong kecil-kecil dan ditimbang sebanyak 25 gram

b) Ditambah $100 \mathrm{~mL}$ akuades, kemudian disaring menggunakan kertas saring dan dimasukkan ke dalam labu ukur $100 \mathrm{~mL}$

c) Dipipet $5 \mathrm{~mL}$ filtrat dan dimasukkan ke dalam tabung reaksi

d) Ditambahkan campuran asam kromatofat, asam fosfat dan hidrogen peroksida. Terbentuknya warna merah keunguan menunjukkan bahwa sampel positif mengandung Formalin.

\subsubsection{Uji Kuantitatif Formalin (Spektrofotometer)}

\section{Pembuatan larutan standar}

a) Sebanyak 2,2 mL formalin $37 \%$ dimasukkan ke dalam labu takar $100 \mathrm{~mL}$ dan ditambahkan akuades hingga garis tanda batas.

b) Dari larutan baku induk formalin dibuat konsentrasi $100 \mathrm{ppm}, 150 \mathrm{ppm}$, 200 ppm, 250 ppm dan 300 ppm dengan mengukur 1,2 mL larutan induk untuk konsentrasi $100 \mathrm{ppm}, 1,8 \mathrm{~mL}$ untuk konsentarsi $150 \mathrm{ppm}, 2,4 \mathrm{~mL}$ untuk konsentrasi $200 \mathrm{ppm}, 3,0 \mathrm{~mL}$ untuk konsentrasi $250 \mathrm{ppm}$ dan 3,6 $\mathrm{mL}$ untuk $300 \mathrm{ppm}$. Masing-masing konsentrasi dimasukkan ke dalam labu takar $100 \mathrm{~mL}$ dan ditambahkan akuades sampai garis tanda batas. Diukur absorbansi dari masing-masing konsentrasi dengan menggunakan spektrofotometer.

c) SatumL larutan formalin konsentrasi $100 \mathrm{ppm}$ dimasukkan ke dalam tabung reaksi tertutup dan ditambahkan akuades $9 \mathrm{~mL}$ serta $5 \mathrm{~mL}$ pereaksi Nash. Larutan dipanaskan dalam penangas air pada suhu $37^{\circ} \mathrm{C}$ selama 30 menit kemudian didinginkan. Larutan dipindahkan secara kuantitatif ke dalam labu takar $25 \mathrm{~mL}$ dan ditambahkan akuades sampai garis tanda batas.Serapannya diamati menggunakan ala spektrofotometer UV-Vis hingga didapat panjang gelombang maksimum $400-600 \mathrm{~nm}$.

\subsubsection{Penetapan formalin pada sampel bakso}

a) Sampel ditimbang sebanyak 10 gram dan dimasukkan ke dalam labu destilasi. Ditambahkan $100 \mathrm{~mL}$ akuades dan $10 \mathrm{~mL}$ asam fosfat $10 \%$. Hasil destilasi ditampung ke dalam labu takar $100 \mathrm{~mL}$ yang telah berisi $10 \mathrm{~mL}$ akuades (ujung pendingin dicelup) dan dilakukan destilasi hingga diperoleh destilat sampai tanda batas, dikocok sampai homogen.

b) Sebanyak $1 \mathrm{~mL}$ destilat dimasukkan ke dalam tabung reaksi tertutup. Destilat ditambah $9 \mathrm{~mL}$ akuades dan $5 \mathrm{~mL}$ pereaksi Nash lalu dipanaskan dalam penangas air pada suhu $37^{\circ} \mathrm{C}$ selama 30 menit lalu didinginkan. Larutan dipindahkan secara kuantitatif ke dalam labu takar $25 \mathrm{~mL}$ dan ditambah akuades sampai garis tanda batas. Absorbansinya dibaca menggunakan alat spektrofotometer UV-Vis (Susanti, 2010).

\subsection{Variabel Penelitian}

AdapunVariabel yang diamati dalam penelitian ini adalah:

1. Pengujian formalin pada bakso secara kualitatif dilakukan untuk melihat ada atau tidaknya formalin di dalam bakso, sedangkan pengujian secara kuantitatif untuk melihat kadar formalin yang terkandung di dalam bakso.

2. Pengujian boraks pada bakso secara kualitatif dilakukan untuk melihat ada atau tidaknya formalin di dalam bakso, sedangkan pengujian secara kuantitatif untuk melihat kadar boraks yang terkandung di dalam bakso.

\section{HASIL DAN PEMBAHASAN}

Secara demografis penduduk Kecamatan Kota Kefamenanu didominasi oleh laki-laki sebanyak 21.315 orang atau 50,08\% sementara perempuan sebanyak 21.246 orang dengan presentase adalah $49,92 \%$ dari total keselurahan 42.561 orang yang tersebar di 8.732 Kepala Keluarga (KK). Mata Pencaharian masyarakat di Kecamatan Kota Kefamenanu terdapat beberapa jenis pekerjaan antara lain petani/peternak, pensiunan, PNS, Pegawai Swasta, TNI, POLRI dan Wiraswasta.

Industri pengolahan daging sapi menjadi bakso yang ada di kota Kefamenanu Kabupaten Timor Tengah Utara (TTU) sejauh ini telah berkembang dengan baik, dan penyebarannya hampir merata mulai dari Kelurahan Kefamenanu Selatan, Kefamenanu Tengah, Benpasi, Maubeli dan Sasi, yang beroperasi sebagai industri kuliner.

Bakso yang merupakan bola daging hasil campuran tepung tapioka dan daging digemari berbagai lapisan masyarakat, dengan harga yang relative murah dan mudah didapat. Akses yang murah serta banyak peminat menjadikan bakso sebagai salah satu alternatif pilihan menu hasil olahan daging sapi. Adapun karakteristik responden (pemilik produk) bakso yang diambil sebagai sampel seperti disajikan dalam Tabel 2 sebagai berikut:

Tabel 2. Karakteristik Responden (Produsen/penjual) Bakso di Kota Kefamenanu, Tahun 2020

\begin{tabular}{ccc}
\hline \hline Kategori & Jumlah & Persentase (\%) \\
\hline Umur & & 20 \\
Muda & 4 & 55 \\
Sangat Produktif & 11 & 25 \\
Produktif & 5 & \\
Pendidikan & & 10 \\
SD & 2 & 40 \\
SMP & 8 & 45 \\
SMA & 9 & 5 \\
Sarjana & 1 & \\
Lama Usaha & & 50 \\
23-8 tahun & 10 & 25 \\
9-13 tahun & 5 & 10 \\
14-18 tahun & 2 & 15 \\
19-23 tahun & 3 &
\end{tabular}

Sumber: Data diolah, (2020)

Deskripsi responden untuk faktor Umur pada Tabel 2 di ata menunjukkan bahwa karakteristik responden pada kategori umur didominasi oleh responden dengan umur 38-46 tahun yang juga dikategorikan sebagai umur yang sangat Produktif yaitu sebanyak 11 orang (55\%), menyusul umur 47-55 tahun (umur produktif) sebanyak5 orang $(25 \%)$, dan terakhir umur $\leq 37$ tahun (kategori umur muda) sebanyak 4 org (20\%). Dengan kisaran umur tersebut menunjukan bahwa kecenderungan para produsen yang mengelolah usaha kuliner bakso pada usia sangat produktif sehingga minat untuk mengetahui hal baru dan usaha yang gigih dalam berproduksi masih sangat tinggi terutama untuk meningkatkan pendapatan dalam keluarga. Umur pengusaha menjadi suatu faktor yang mempengaruhi kemampuan fisik seseorang dalam mengelola usaha. Hal ini sesuai dengan hasil penelitian Suwarta. (2012), bahwa semakin bertambah umur seseorang akan mengakibatkan produktivitasnya semakin menurun. Lebih lanjut dijelaskan bahwa dalam proses adopsi inovasi baru, orang yang berumur produktif akan lebih tanggap bila dibandingkan dengan yang berumur lebih tua (tidak produktif).

Aspek tingkat pendidikan menunjukkan pengetahuan dan kemampuan daya pikir yang dimiliki oleh seorang responden yang dapat berpengaruh terhadap kematangan dirinya dalam bersikap, pengambilan keputusan dan berperilaku (Pane, 2003). Karakteristik responden berdasarkan tingkatan pendidikan menunjukkan bahwa pengusaha bakso di Kota Kefamenanu mayoritas berpendidikan SMA, dengan rincian tamat SD sebanyak 2 orang 
(10\%); pendidikan SMP 8 orang (40\%), untuk tingkat pendidikan SMA 9 orang $(45 \%)$ dan yang berpendidikan Sarjana sebanyak 1 orang $(5 \%)$. Pendidikan menunjukkan tingkat intelegensi yang berhubungan dengan daya pikir seseorang. Tingkat pendidikan responden masih tergolong menengah yang berarti masih perlu pendampingan untuk meningkatkan pengetahuan mereka, sehingga pada gilirannya dapat meningkatkan produksi dan produktivitas usahanya. Tingkat pendidikan yang rendah dapat menyebabkan seseorang kurang mempunyai keterampilan tertentu yang diperlukan dalam kehidupannya (Ahmadi, 2003).

\subsection{Pengujian Boraks Pada Bakso}

Hasil pemeriksaan terhadap kandungan boraks terhadap 20 (dua puluh) sampel bakso yang diperoleh dari warung/rumah makan bakso yang tersebar di Kota Kefamenanu seperti terlihat pada Tabel 3.

Tabel 3. Hasil Uji Kandungan Boraks pada Bakso yang dijual di Kota Kefamenanu, Tahun 2020

No Nama Sampel ${ }_{\text {Uji Kualitatif Boraks }}{ }^{\text {No Nama Sampel }}{ }_{\text {Uji Kualitatif Boraks }}$

\begin{tabular}{cccccc}
\hline 1 & S1 U & Negatif & 11 & S11 BK & Negatif \\
2 & S2 SS & Negatif & 12 & S12 BPLN & Negatif \\
3 & S3 SPB & Negatif & 13 & S13 BSA1 & Negatif \\
4 & S4 A5 & Negatif & 14 & S14 SA2 & Negatif \\
5 & S5 BK & Negatif & 15 & S15 SA3 & Negatif \\
6 & S6 DSP & Negatif & 16 & S16 BT1 & Negatif \\
7 & S7 GR & Negatif & 17 & S17 BT2 & Negatif \\
8 & S8 SAY1 & Negatif & 18 & S18 BT3 & Negatif \\
9 & S9 CDL & Negatif & 19 & S19 BSM & Negatif \\
10 & S10 CRS & Negatif & 20 & S20 BSS & Negatif \\
\hline \multicolumn{7}{l}{ Sumber: Hasil Uji Laboratorium MIPA Unika Widya Mandira Kupang, 2020. }
\end{tabular}

Hasil uji sampel menunjukkan bahwa semua sampel bakso yang diuji boraks menggunakan larutan kurkumin tidak ditemukan adanya boraks dalam bakso tersebut. Artinya produsen yang menjual bakso di Kecamatan Kota Kefamenanu, Kabupaten Timor Tengah Utara 100\% tidak menggunakan bahan pengenyal boraks (Natrium Tetraborat) yang merupakan senyawa kimia mengandung unsur boron dengan rumus molekul Na2B4O7. 10H2O. Hal ini mengindikasikan bahwa pihak produsen (pemilik warung bakso) sudah menyadari akan bahaya dari efek kandungan boraks bagi kesehatan manusia sehingga para produsen telah memperhatikan betul kualitas bakso yang diproduksi terutama dari tingkat kekenyalannya. Ciri bakso yang mengandung boraks akan lebih kenyal dibanding bakso tanpa boraks (Putra, 2009).

\subsection{Pengujian Formalin Pada Bakso}

Hasil pemeriksaan terhadap kandungan formalin sampel bakso yang diperoleh dari warung/rumah makan bakso yang tersebar di Kota Kefamenanu seperti terlihat pada Tabel 4.

Tabel 4. Hasil Uji Kandungan Formalin pada Bakso yang dijual di Kota Kefamenanu, Tahun 2020

\begin{tabular}{lccccc}
\hline No & $\begin{array}{c}\text { Nama } \\
\text { Sampel }\end{array}$ & $\begin{array}{c}\text { Uji Kualitatif } \\
\text { Formalin }\end{array}$ & No & $\begin{array}{c}\text { Nama } \\
\text { Sampel }\end{array}$ & $\begin{array}{c}\text { Uji Kualitatif } \\
\text { Formalin }\end{array}$ \\
\hline 1 & S1 U & Negatif & 11 & S11 BK & Negatif \\
2 & S2 SS & Negatif & 12 & S12 BPLN & Negatif \\
3 & S3 SPB & Negatif & 13 & S13 BSA1 & Negatif \\
4 & S4 A5 & Negatif & 14 & S14 SA2 & Negatif \\
5 & S5 BK & Negatif & 15 & S15 SA3 & Negatif \\
6 & S6 DSP & Negatif & 16 & S16 BT1 & Negatif \\
7 & S7 GR & Negatif & 17 & S17 BT2 & Negatif \\
8 & S8 SAY1 & Negatif & 18 & S18 BT3 & Negatif \\
9 & S9 CDL & Negatif & 19 & S19 BSM & Negatif \\
10 & S10 CRS & Negatif & 20 & S20 BSS & Negatif \\
\hline Sumber: Hasil Uji Laboratorium MIPA Unika Widya Mandira Kupang, 2020
\end{tabular}

Sumber: Hasil Uji Laboratorium MIPA Unika Widya Mandira Kupang, 2020.

Pada Tabel 4 menunjukkan bahwa hasil analisis kandungan formalin pada bakso diwilayah Kota Kefamenanu adalah 0\% (negatif) tidak mengandung fromalin untuk semua produsen/pedagang mulai dari kode sampel S1 U,S2 SS,
S3 SPB,S4 A5,S5 BK, S6 DSP, S7 GR, S8 SAY1, S9 CDL,S10 CRS, S11 BK, S12 BPLN, S13 BSA1, S14 SA2, S15 SA3, S16 BT1, S17 BT2, S18 BT3, S19 BSM, dan S20 BSS (100\% tidak ada yang menggunakan formalin). Walaupun hasil Uji kualitatif formalin menggunakan Asam Kromatofat negative, masyarakat perlu mengetahui ciri fisik bakso yang mengandung formalin yaitu lebih pucat dari warna bakso aslinya (tidak mengandung formalin) dan bau khas daging yang hilang. Keberadaan formalin bagi tubuh manusia diketahui sebagai zat beracun, karsinogen (menyebabkan kanker), mutagen (menyebabkan perubahan sel, jaringan tubuh), korosif dan iritatif. Penggunaan formalin jangka panjang pada manusia dapat menyebabkan kanker mulut dan tenggorokan (Putrianti, 2009)

\section{PENUTUP}

\section{1 kesimpulan}

Berdasarkan hasil dan pembahasan sebagai mana telah diuraikan maka dapat disimpulkan bahwa Produsen atau penjual bakso di Kota Kefamenanu, Kabupaten Timor Tengah Utara tidak menggunakan boraks sebagai bahan pengeyal bakso dan Formalin sebagai bahan pengawet pada pembuatan bakso.

\section{DAFTAR PUSTAKA}

Aminah dan Himawan. 2009. Bahan-bahan Berbahaya dalam Kehidupan Bandung.

Arsyad M. Y., Taha S. R., dan M. S. Mas'ud. 2019. Uji Kualitatif Boraks dan Formalin pada Bakso yang Dijual di Kecamatan Limboto Kabupaten Gorontalo. Jurnal Kajian Veteriner, 3 (1): 11-15.

Bani, M. 2003 Kualitas Mikrobiologis Pada Bakso Yang Dijual Secara Stationer Dan Yang Diuji Secara Berkeliling Di Kota Kupang. Skripsi Fapet Undana.

Cahyadi, W. 2006. Analisis \& Aspek Kesehatan Bahan Tambahan Pangan, Ce. I. Bumi Askara: Jakarta.

Hamm, R. 2981. Post-mortem Changes In Muscle Affecting The Quality Of Comminuted Meat Products. In: Lawrie, R. (Ed). Developments in meat science 2. Applied Science Publisher, London.

Indrati, R. dan Murdijati Gardjito. 2014. Pendidikan Komsumsi Pangan Edisi I Cetakan I. Jakarta; Kencana.

Issusilaningtyas, E \& Swandari, M. T. K. 2016. Analisa Kandungan Boraks Sebagai Zat Pengawet pada Jajanan Bakso. Jurnal Kesehatan Al-Irsyad (JKA), IX(1).

Judarwanto, Widodo Spa. 2006. Formalin Terhadap Sistem Tubuh. Dikutip Melalui Http;//Putrakembara.Org/Index.Shtml (22 Mei 2014).

Kramlich, R. V. 1971. Sausage Product. San Fransisco; W. H. Freeman And Company.

Kresnadipayana D, Lestari D. 2017. Penentuan Kadar Boraks Pada Kurma (Phenix dactylifera) Dengan Metode Spekrofotmetri uv-vis. Jurnal Wiyata, 4(1):23-30

Lubiana, D. N. 2008. Pengaruh Penggunaan Berbagai Jenis Tepung Dan Daging Sapi Terhadap Kualitas Fisik Sosis. Fakultas Peternakan. Undana.

Lukman. 2010. Sifat Fisik dan Palatabilitas Bakso Daging Sapi dan Daging Kerbau Pada Lama Postmortem yang Berbeda. Skripsi. Fakultas Peternakan, Institut Pertanian Bogor.

Nasution, A. 2009. Analisa Kandungan Boraks Pada Lontong Di Kelurahan Padang Bulan Kota Medan Tahun 2009. Skripsi. Universitas Sumatera Utara. Medan.

Ngudi waluyo, S. dan Suharjito., 2006. Pengaruh Penggunaan Sodium Tripoly Phospat Terhadap Daya Simpan Bakso Sapidalam Berbagai Suhu Penyimpanan.

Peraturan Menteri Kesehatan Republik Indonesia Nomor 033 Tahun 2012 Tentang Bahan Tanbahan Pangan.

Putra, A. K. 2009. Formalin dan Boraks pada Makanan. Institut Teknologi Bandung: Bandung.

Putri, A. F. E., 2009. Sifat Fisik dan Organoleptik Bakso Daging Sapi Pada Lama Postmortem yang Berbeda dengan Pemnambahan Karagenan. Skripsi Hal 40. Fakultas Peternakan. Institut Pertanian Bogor. Bogor.

Salu, C. A. 2003. Pengaruh Lama Penyimpanan Dan Level Bahan Pengawet Gula Lontar Rote (Borassus Sondaicus) Terhadap Kualitas Daging Sapi Bali. Skripsi. Fakultas Peternakan Nusa Cendana.

Soeparno, 1994. Ilmu dan Teknologi Daging. Gadjah Mada University Press: Yogyakarta.

Soeparno, 1998. Ilmu dan Teknologi Daging Cetakan ke tiga. Gadjah Mada University Press:Yogyakarta.

Suklan H., 2002. Apa dan Mengapa Boraks Dalam Makanan. Penyehatan Air dan Sanitasi (PAS).Vol. IV Nomor 7

Sunarlim, R. (1992). Karakteristik Mutu Bakso Daging Sapi dan Pengaruh Penambahan Natrium Klorida dan Natrium Tripolipospat terhadap Perbaikan Mutu. Thesis. Institut Pertanian Bogor. Bogor.

Susanti, S . 2010. Penetapan Kadar Formaldehid pada Tahu yang dijual di Pasar Ciputat dengan Metode Spektrofotometer UV-Vis disertai 
Kolorimetri Menggunakan Pereaksi Nash.[Skripsi]. Jakarta: Fakultas Kedokteran dan Ilmu Kesehatan, Universitas Islam Negeri (UIN) Syarief Hidayahtullah: Jakarta

Undang-Undang Republik Indonesia Nomor 18 Tahun 2012 Tentang Pangan

Wibowo. 1999. Pembuatan Bakso Ikan dan Bakso Ikan. PT. Penebar Swadaya: Jakarta.

Widayat, D. 2011. Uji Kandungan Boraks pada Bakso (Studi pada Warung Bakso di Kecamatan Sumber sari Kabupaten Jember). [Skripsi]. Jember: Bagian Kesehatan Lingkungan dan Kesehatan Keselamatan Kerja Fakultas Kesehatan Masyarakat, Universitas Jember

Wuri, D.A. 2006. Kajian Mikroskopik Berbagai Jenis Jaringan dan Proporsi Daging Pada Bakso Daging Sapi yang Dijual di Bogor (tesis). Bogor Sekolah Pascasarjana, Institut Pertanian Bogor.

Yuliarti, N. 2007. Awas Bahaya Di Balik Lezatnya Makanan. Yogyakarta 